\title{
Analisis Pendapat Khalifah Umar Bin Khațțāb tentang Penundaan Penarikan Zakat Binatang Ternak Kambing yang Telah Mencapai Nisab
}

\author{
Ahmad Munif \\ Institut Agama Islam Negeri (IAIN) Walisongo Semarang \\ munif060386@gmail.com
}

\begin{abstract}
:
Caliph Umar ibn al-Khațāa had delayed withdrawal charity goats. Though there are number of goats has reached nishab. It is applied to an area in the Hejaz region whwn it was hit by drought. Of course this is being debated. Though Umar is one of the companions are known firm ini carrying out their religious duties. The results of this research are, first, the withdrawal delay zakat animals that have reached only apply to animals that have been hit by the famine years (ramädah). Umar's policy gave alms to the people who have goats nishab number based on the condition of the person is also experiencing difficulties. One henred goat that he had no significant influence on survival at the time. Umar suspending withdrawal zakat to muzakki despite his wealth has reached nishab, due to difficulties and distress. Second, the vocabulary knowledge of figh, delay the withdrawal of zakat is must. Althought the jurist. Emphasizes that zakat is paid immediately. What is done by delaying the withdrawal of zakat Umar made one considered by some scholars to allow delaying the payment of zakat. And third, the condition of indonesia's disaster-prone, makes delay the withdrawal of zakat by Umar could be pne of the considerations to delay payment of zakat to an area back to the state as usual.
\end{abstract}

Keywords: Delays, nishab, goat.

\section{Abstrak:}

Khalifah Umar bin khattab pernah menunda penarikan zakat ternak kambing. Padahal jumlah kambing yang ada telah mencapai nishab. Hal ini diberlakukan kepada satu wilayah di daerah hijaz yang saat itu sedang terk ena musibah kekeringan. Tentu ini menjadi polemik. Padahal Umar merupakan salah satu sahabat yang dikenal tegas dalam melaksanakan kewajiban agama. 
Hasil dari penelitian ini adalah, pertama, Penundaan penarikan zakat binatang ternak yang telah mencapai nishab hanya diberlakukan kepada binatang ternak yang terkena imbas dari musim paceklik tahun ramadah. Kebijakan Umar memberikan zakat kepada orang yang memiliki kambing sejumlah nishab dilandasi oleh kondisi orang tersebut juga mengalami kesukaran. Seratus kambing yang ia miliki tidak memberi pengaruh berarti terhadap kelangsungan hidupnya pada saat itu. Umar menangguhkan penarikan zakat kepada muzakki meski hartanya telah mencapai nishab, karena mengalami kesulitan dan kesusahan. Kedua, dalam khazanah ilmu fiqh, penundaan penarikan zakat merupakan suatu keniscayaan. Meskipun para fuqaha' lebih mengedepankan agar zakat dibayarkan segera. Apa yang dilakukan Umar dengan menunda penarikan zakat dijadikan salah satu pertimbangan oleh beberapa ulama dalam membolehkan menunda pembayaran zakat. Dan ketiga, Kondisi Indonesia yang rawan bencana, menjadikan penundaan penarikan zakat oleh Umar bisa menjadi salah satu pertimbangan untuk menunda pembayaran zakat hingga suatu daerah kembali ke keadaan seperti sedia kala.

Kata Kunci: Menunda, nishab, kambing.

\section{Pendahuluan}

Zakat merupakan ibadah dan kewajiban sosial bagi para aghniya' (hartawan) setelah kekayaannya memenuhi batas minimal (nishab) dan rentang waktu setahun (haul). Tujuannya untuk mewujudkan pemerataan keadilan dalam ekonomi. Sebagai salah satu aset -lembaga- ekonomi Islam, zakat merupakan sumber dana potensial strategis bagi upaya membangun kesejahteraan umat (Rofiq, 2004: 259).

Untuk dapat mewujudkan keinginan di atas, seorang muslim harus memenuhi syarat wajib zakat. Zakat sebagai ibadah mâliyah (kebendaan) baru diwajibkan ketika seseorang memiliki harta dan memenuhi syarat sebagai berikut: (1) Islam; (2) Merdeka; (3) kepemilikan terhadap harta sempurna; (4) Cukup satu nishab (batas minimal wajib zakat); (4) satu tahun (haul), untuk beberapa jenis zakat (Rofiq, 2004: 266).

Ketika syarat-syarat di atas terpenuhi, maka tiap tahun orang tersebut wajib mengeluarkan zakat. Wahbah Zuhailiy dalam bukunya al-Fiqhul Islam wa Adillatuhu menjelaskan, dengan memperhatikan jenis bendanya, maka 
zakat mal (emas dan perak), harta dagangan, dan binatang ternak yang telah sempurna haulnya, diwajibkan mengeluarkan zakat setiap tahun sekali (Zuhaili, t.t: 1418).

Hasbi Ash-Shidiqie menuturkan, penguasa wajib memungut zakat dari muzakki (orang yang wajib membayar zakat) (1996: 49). Ia mendasarkan pada QS. At-Taubah ayat 103 dan hadits yang diriwayatkan oleh Bukhary dari Ibnu Abbas: bahwa Rasulullah saw. bersabda;

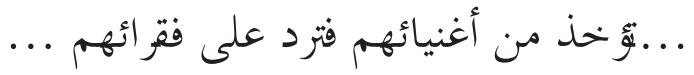

Artinya:

"Diambil (zakat) dari orang-orang kaya mereka, lalu diberikan kepada orang-orang fakir mereka."(An-nasa'i, 1995: 19)

Berdasar hadis ini, para penguasa mempunyai hak mengurusi zakat, baik itu menerima atau mendistribusikan, sendiri. Atau dengan membentuk naib (wakil/badan) untuk mengurusi zakat. Dengan adanya hadits ini pula barang siapa enggan membayar zakat, maka para penguasa boleh mengambil dengan cara paksa.(Ash-Shiddiqie, 1996: 19).

Menilik pada sejarah, pada awal kelahiran Islam zakat langsung ditangani langsung oleh penguasa pada masa itu. Pada saat Nabi Muhammad saw. masih hidup, Nabi senantiasa mengutus petugas untuk mengambil zakat (Qarḍāwi, 2004: 736). Dan memang pada masa awal Islam, zakat merupakan pendapatan negara, yang dikelola Nabi langsung dan kemudian dilanjutkan Khalifah Abu Bakar dan Umar bin Khaț̣āb. Imam Baihaqi telah meriwayatkan dari Imam Syafi'i bahwa Abu Bakar dan Umar telah mengutus petugas untuk mengambil zakat. Ia menambahkan, bahwa mereka tidak pernah mengakhirkan dalam pengambilan zakat di setiap tahunnya.

Pada masa Khalifah Umar bin Khațțāb, penarikan zakat tetap ditegakkan. Namun ada satu masa dimana Umar menangguhkan penarikan zakat binatang ternak kambing yang telah mencapai nishab. Apa yang diperbuat ini belum pernah ada sebelumnya pada masa Nabi Muhammad saw. maupun Abu Bakar. Boleh dikatakan, ini murni ijtihad Umar bin Khatțāb dalam menghadapi persoalan umat. 
Ada beberapa alasan dalam menentukan fokus penelitian ini. Pertama, zakat adalah persoalan umat. Zakat pada masa awal perkembangan Islam merupakan salah satu sumber utama pendapatan dalam baitul mal (Hasjmi, 1979: 82-83). Sehingga ketika seorang Umar mengeluarkan pendapat untuk menunda penarikan zakat ini, secara tidak langsung akan berimplikasi terhadap keberadaan baitul mal pada saat itu. Tentu kita patut menyelidiki apa latar belakang Umar yang dikenal sebagai sosok yang tegas dan cerdas mengeluarkan pendapat ini. Mengenai kedalaman ilmu Umar, Nabi Muhammad saw pernah bersabda, "Ketika aku tertidur, aku bermimpi meminum susu, sehingga aku melihat kesegaran mengalir di kukuku, kemudian aku berikan kepada Umar." Maka para sahabat bertanya, "Apa makna demikian itu ya Rasulullah?" beliau berkata, "Ilmu." (Al-Harithi, 2006: 23). Umar dalam menanggapi persoalan berusaha menyelesaikan dengan bijak serta mengedepankan kemaslahatan bersama. Termasuk di antaranya soal penundaan penarikan zakat bintang ternak kambing ini.

Kedua, dalam khazanah fiqih, kita hanya menemukan aturan dan norma yang menjelaskan bagaimana menunaikan zakat jika telah memenuhi syarat dan rukun yang ada saja. Namun tidak banyak kita jumpai bagaimana seandainya bila seorang muzakki menunda pembayarannya karena alasan tertentu atau amil dengan pertimbangan tertentu melakukan penundaan pemungutan zakat.

Dengan demikian, keberanian dan kecerdasan Khalifah Umar untuk mengambil langkah yang belum ada pada era Nabi Muhammad saw. dan Khalifah Abu Bakar dalam menghadapi problem kesulitan di masa itu cukup urgen untuk diteliti. Inilah beberapa faktor yang mendorong penulis tertarik untuk meneliti pendapat Khalifah Umar bin Khaț̣āb lebih jauh.

Berangkat dari gambaran di atas, ada tiga pertanyaan yang diajukan. Pertama, bagaimana pendapat Umar bin Khaț țāb tentang penundaan penarikan zakat binatang ternak kambing yang telah mencapai nishab. Kedua, bagaimana keberadaan pendapat Khalifah Umar bin Khaț̣āb tentang penundaan penarikan zakat binatang ternak kambing dalam khazanah ilmu fiqh. Dan ketiga, bagaimana kontekstualisasi pendapat Umar bin Khațāa ini dengan pengelolaan zakat di Indonesia. 


\section{Metode Penelitian}

Penelitian ini termasuk jenis penelitian kepustakaan (library research). Sehingga penelitian ini berupaya melakukan pengkajian dan penelaahan terhadap literatur yang tekait dengan tema yang penulis angkat, yakni penundaan penarikan zakat binatang ternak menurut Khalifah Umar bin Khaț̣āb.

Dalam penelitian secara umum, sumber data dibedakan atas sumber data primer dan sumber data skunder. Sepengetahuan penulis, dalam penelitian pendahuluan, Khalifah Umar bin Khaț̣āb tidak meninggalkan karya yang bisa dikategorikan sebagai sumber primer. Namun demikian penulis dapat memperoleh data primer dari Ibnu Sa'ad dalam bukunya, Thabaqat Al-Kubra. Sedangkan data sekunder diperoleh dari buku karya Abu Ubaid yang bertitel Al-Amwal. Dalam penelitian ini penulis juga mengumpulkan data dari berbagai sumber yang memberikan informasi tentang pendapat Khalifah Umar bin Khaț̣āb mengenai penundaan penarikan zakat binatang ternak kambing yang telah mencapai nisab. Misalnya, buku Al-Fiqhi Al-Iqtiṣādi Li Amīri al-Mukminīna Umar Ibni Al-Khațțāb, yang diterjemahkan menjadi Fikih Ekonomi Umar Bin Khaț̣āb, karya Dr. Jaribah bin Ahmad al-Harithi, Yusuf Qaradhawi dalam magnum opus-nya yang bertitel Fiqh Zakat (terj. Hukum zakat) juga menyinggung tentang perilaku Umar ini, kemudian kitab yang disusun Muhammad Rowasy Qal'ahjay yang berjudul, Mausū'ah Fiqh Umar ibn Khațtāb, dan. Ada juga buku karangan Muhammad Ridho yang berjudul Umar bin Khatțāb al-Fārūq. Buku ini berisi sejarah hidup Umar dari awal hingga akhir. Juga mengisahkan bagaimana Khalifah Umar bin Khațtāb menghadapi paceklik, yang salah satunya membuat beliau berpendapat perlunya menunda penarikan zakat binatang ternak. Dan buku-buku lain yang memberi informasi tentang pendapat Khalifah Umar untuk menunda penarikan zakat binatang ternak kambing yang telah mencapai nishab pada tahun paceklik.

Karena penelitian ini tergolong dalam jenis penelitian kepustakaan, maka untuk mendapatkan data peneliti melakukan pencarian dan pengumpulan melalui studi kepustakaan untuk mendapatkan buku maupun literatur yang relevan dengan pokok bahasan. 
Dalam penelitian ini, penulis menggunakan metode analisis deskriptif, yaitu dengan memaparkan kembali data yang sudah ada sebelumnya. Selanjutnya menganalisa data tersebut secara logis dan sistematis untuk menguji tingkat akurasi data yang sudah ada.

Penulis juga akan menggunakan metode usuliyah. Metode ini digunakan untuk memahami hakikat pendapat Khalifah Umar bin Khatṭāb dalam menetapkan penundaan penarikan zakat binatang ternak kambing yang telah mencapai nishab. Karena pendapat Umar dalam persoalan ini berbeda dengan apa yang dilakukan Nabi Muhammad saw. dan Khalifah Abu Bakar. Dengan kata lain, apa yang dilakukan Umar menyimpang dari makna tekstual dan kebiasaan Umar sendiri pada tahun-tahun sebelumnya dalam menarik zakat.

Penelitian ini akan menggunakan pendekatan sejarah (histories). Metode ini digunakan agar sebisa mungkin penulis memasuki kedaan sebenarnya berkenaan dengan pemaparan suatu peristiwa, yaitu kondisi dimana Umar mengeluarkan pendapat tentang penundaan penarikan zakat binatang ternak kambing yang telah mencapai nishab.

\section{Biografi Umar bin Khațțāb}

Umar dilahirkan 30 tahun sebelum masa kenabian. Muhammad Ridho, (t.t: 8-9), Muhammad Ali Quṭb menyebutkan, Umar lahir tiga belas tahun setelah tahun gajah, yakni tahun kelahiran Nabi Muhammad s.a.w. yang bertepatan dengan tahun $570 \mathrm{M}$ (Quṭb, t.t: 76). Ia hidup selama 65 tahun. Ibnu Kathīr menyebutkan adanya perselisihan tentang berapa usia Umar. Beberapa di antaranya menyebutkan, umur Umar 55 tahun, 63 tahun, dan 57 tahun. (Ibnu Katsir, 187; Lihat juga Jalaluddin Al-Suyuṭi, dalam Tārikh al-Khulafá', t.t: 108). Separuh hidupnya dihabiskan dalam masa jahiliyyah. Pada masa ini, Umar sama sekali tidak dikenal. Namun semua berubah ketika masuk Islam, namanya menjadi terkenal dan termasuk salah satu tokoh besar (Jaribah, 2006: 18).

Umar masuk Islam ketika berusia 27 tahun. Beliau mengikuti Perang Badar dan peperangan yang terjadi setelahnya bersama Rasulullah SAW. Beliau juga pernah diutus berangkat bersama sebagian tentara untuk memata- 
matai dan mencari informasi tentang musuh, terkadang menjadi pemimpin dalam tugas ini (Ibnu Katsir, 2005: 170).

Nabi Muhammad SAW. mempersaksikan keilmuan dan pemahaman Umar yang tidak beliau lakukan kepada selainnya. Sebagaimana dalam sabda beliau; "Ketika aku tidur bermimpi minum susu sehingga aku melihat kesegaran mengalir di kukuku, kemudian aku berikan kepada Umar." Maka para sahabat berkata, "Apa makna demikian itu, ya Rasulullah?" beliau berkata, "Ilmu." (Ibnu Katsir, 2005: 173. Quṭ, t.th: 85-86).

Abdullah bin Mas'ud menyifati ilmu Umar seraya mengatakan, "Seandainya ilmu Umar diletakkan di piringan timbangan yang satu, dan ilmu orang-orang yang hidup di bumi diletakkan di piringan timbangan yang lain, niscaya ilmu Umar mengungguli ilmu mereka. Sungguh mereka (para sahabat) berpendapat bahwa dia pergi dengan 90\% ilmu." Umar bin Khatțāb terkenal sebagai seorang khalifah yang berani berijtihad, terutama dalam menyelesaikan persoalan-persoalan hukum, yang kadang-kadang keputusannya dalam bidang hukum ini dipandang sebagai bertentangan dengan nash (Sholikin, 2005: 16).

Umar dalam ijtihadnya memakai berbagai metode yang dipakai ulama ushulliyyin yang lahir 2 abad seteleh kematiannya. Sebagaimana ahli fiqh pada umumnya, Umar juga mempunyai metode dalam menetapkan suatu hukum. Meskipun, mungkin, Umar dulu tidak mengetahui dan mengklasifikasikan metode apa yang ia pakai. Namun setidaknya ada ciriciri tertentu yang dipakai Umar dalam mengemukakan suatu pendapat hukum. Hal ini yang dilakukan Dr. Muhammad Baltaji dalam bukunya Manhaj Umar bin Khațtāà fi Al-Tasyrī'; Dirāsah Mustau'ibah li Fiqh Umar wa Tandhimihi yang diterjemahkan ke dalam bahasa Indonesia menjadi Metodologi Ijtihad Umar bin Khattāă.

Baltaji menguraikan, umar menggunakan al-Qur'an dan sunnah rasul sebagai landasan utama. Metode qiyas, istiṣlāh, sad al-dharì'ah dan istiḥsān juga dipakai oleh umar dalam berijtihad. 


\section{Pandangan Umar bin Khattab tentang Zakat}

Hudhori bek menerangkan, dalam pandangan Umar, zakat merupakan satu dari beberapa rukun Islam yang ada. Syari'at telah memerintahkan agar mengambil zakat dari orang-orang kaya (aghniyā') dan memberikannya kepada fuqarā' (1982: 112).

Menurut Umar, zakat merupakan fardhu yang telah difardhukan (diwajibkan) Allah kepada muslimin. Orang yang menunaikan zakat akan mendapat ajr (pahala) dari Allah (Rowasy, 1981: 351).

Pada masa pemerintahan Umar, zakat merupakan sumber pendapatan utama negara Islam. Zakat dijadikan ukuran fiskal utama dalam rangka memecahkan masalah ekonomi secara umum (Ashraf, 1990: 85). Hukuman berat akan diberlakukan bagi orang yang tidak mau membayar zakat, sehingga orang yang tidak mau membayar zakat dapat didenda sebesar $50 \%$ dari jumlah kekayaannya sebagaimana dinyatakan oleh Rasulullah sendiri, "Orang yang tidak mau membayar zakat, akan saya ambil zakatnya dan setengah dari seluruh kekayaannya." Inilah salah satu keputusan yang sungguh diakui sebagai kepentingan dan kebenaran oleh Umar. Pengakuan ini dapat dilihat jelas dari pendapatnya tentang tindakan Abu Bakar yang amat tegas terhadap suku-suku yang tidak mau membayar zakat (1990: 87).

Abu Bakar mengatakan,

"Demi Allah, akan saya perangi mereka yang membedakan antara kewajiban ibadah dan kewajiban membayar zakat, karena zakat berurusan dengan harta benda. Ya Allah, jika mereka menghindari kewajiban mereka membayar zakat kepada saya, walau hanya seekor anak kambing, yang seharusnya itu telah mereka bayar kepada Rasulullah, saya akan perangi mereka, saya akan perangi mereka karena penolakannya itu." (Ashraf, 1990: 87-88).

Dengan mengacu kepada ucapan Abu Bakar itulah, Umar menyatakan, "Demi Allah, dia telah membukakan hati Abu Bakar (untuk menerima kebenaran), karena saya tahu bahwa itulah sikap yang benar."

Umar memahami benar tujuan utama kewajiban zakat, yakni mencegah menumpuknya harta di bawah kekuasaan sekelompok kecil. Oleh 
sebab itu, agar distribusi kekayaan di kalangan umat dapat berjalan secara adil dan merata, zakat harus diambil dari orang kaya untuk dibagikan kepada orang miskin. Untuk mencapai tujuan ini, dia membuat berbagai kebijaksanaan dengan menambah jenis barang yang wajib dizakati bila dirasa perlu dan menghilangkannya jika dianggap sudah tidak relevan bagi struktur perpajakan pada waktu itu.

Kitab Mausū'ah Fiqh Umar bin Khațtab (Rowasy, 1981) menguraikan berbagai macam pandangan Umar dalam persoalan fiqh, termasuk di antaranya zakat. Umar menetapkan syarat-syarat seorang muzzakki, yaitu: (1) Islam; (2) Merdeka (hurriyyah); harta yang berada (milik) di tangan seorang budak, tidak wajib zakat. Seorang hamba sahaya itu tidak memiliki harta. Yang ada di tangannya adalah harta milik tuan atau majikannya. Umar berkata; "Tidak ada zakat dalam harta seorang hamba." Seorang budak dari Bani Hasyim bertanya pada Umar, "Saya mempunyai harta, apakah saya harus menzakatinya?" Jawab Umar; "Tidak." Lalu budak tadi bertanya lagi, "Apakah saya boleh bersedekah?" jawab Umar; "(Bersedekah) dengan dirham dan roti." Seorang laki-laki bertanya kepada Umar, "Hai amīru almukminin, apakah zakat diwajibkan kepada budak?" Jawab Umar, "Tidak". Lalu saya bertanya lagi, "Siapa yang wajib membayar zakat?" jawab Umar, "Majikannya."; (3) Secara menyeluruh, bahwa zakat itu diwajibkan atas harta yang dimiliki oleh seorang muslim. Maka sekiranya harta yang dimiliki seorang muslim tersebut telah mencukupi, ia wajib membayar zakat, baik telah mencapai usia baligh atau tidak, berakal atau gila. Berdasarkan hal itu, maka Umar mempertegas mengenai kewajiban zakat seorang yatim yang masih kecil. Oleh karena itu Umar memerintahkan kepada para wali anak yatim untuk mengelola (menginvestasikan) harta anak yatim, sehingga tidak wajib zakat. Lalu berkata, "Dagangkanlah harta anak yatim, supaya tidak termakan zakat." Dan Umar melakukan hal itu, sehingga harta anak yatim bertambah dan ditolak zakatnya."

Umar juga memiliki pandangan mengenai jenis harta yang harus dikeluarkan zakatnya. Harta yang wajib dizakati menurut Umar tercermin dari perintahnya kepada amil yang akan bertugas di Damsyiq, "Sesungguhnya zakat diwajibkan atas pertanian, 'ain (emas dan perak), dan hewan ternak." Akan tetapi keterangan lain menyebutkan, bahwa Umar mewajibkan zakat 
atas hal-hal sebagai berikut, 'ain (emas dan perak) dan barang dagangan, hewan ternak seperi unta, kambing, sapi, setalah itu Umar juga memasukkan kuda, budak, tanaman dan madu.

Menurut Umar, ada beberapa syarat harta yang wajib dizakati: (1) Sempurna nishabnya dan bebas dari hutang; (2) Merupakan harta yang bisa dikembangkan; (3) Mencapai haul; dan (4) Digembalakan, untuk hewan ternak (Rowasy, 1981: 353-355).

Berkenaan dengan nishab zakat kambing, dalam buku Fatwa dan Ijtihad Umar bin Khattab, Muhammad Abdul Aziz al-Halawi menuliskan, diriwayatkan Imam Syafi'i dalam musnadnya, dari Abdullah bin Umar r.a.,bahwa Umar r.a. pernah berkirim surat tentang zakat, yang isinya sebagai berikut:

"Mulai dari lima sampai dua puluh empat ekor unta, maka dalam setiap lima ekornya dikeluarkan zakatnya satu ekor kambing. Dan untuk dua puluh lima sampai tiga puluh lima ekor unta zakatnya satu ekor unta bintu makhă (anak unta betina yang umurnya genap satu tahun dan memasuki tahun kedua). Dan jika tidak ada bintu makhāẹ, maka boleh diganti dengan ibnu labūn (unta jantan yang umurnya genap dua tahun dan memasuki tahun ketiga). Kemudian dalam jumlah di atas tiga puluh lima atau mulai tiga puluh enam sampai empat puluh lima, zakatnya adalah satu ekor bintu labün (unta betina yang umurnya genap dua tahun masuk tahun ketiga. Mulai empat puluh enam sampai enam puluh ekor, zakatnya adalah saru ekor hiqqah (unta betina yang umurnya genap tiga tahun dan memasuki tahun ke empat) yang sudah bisa dikawini oleh pejantan. Mulai dari enam puluh satu sampai tujuh puluh lima ekor zakatnya adalah satu ekot jad'ah (unta yang genap berusia empat tahun dan memasuki tahun kelima). Mulai tujuh puluh enam sampai sembilan puluh satu sampai seratus dua puluh ekor, zakatnya adalah dua ekor hiqqah yang keduanya sudah bisa dikawini oleh pejantan. Kemudian dalam jumlah di atas seratus dua puluh ekor, maka setiap empat puluh ekornya deikeluarkan zakatnya satu ekor bintu labūn, dan untuk setiap lima puluh ekor dikeluarkan zakatnya satu ekor hiqqah. Sedangkan untuk kambing-kambing piaraan yang digembala dengan mencari makan sendiri, apabila telah mencapai empat puluh sampai seratus dua puluh ekor, maka zakatnya satu ekor kambing. Dari seratus dua puluh satu sampai dua ratus ekor, maka dikeluarkan zakatnya dua ekor kambing. Dari dua ratus sampai tiga ratus ekor, 
zakatnya adalah tiga ekor kambing. Kemudian dalam jumlah di atas tiga ratus, maka untuk setiap seratus ekornya dikeluarkan zakatnya satu ekor kambing. Binatang yang sudah tua atau yang buta tidak boleh digunakan untuk zakat. Demikian pula pejantan -karena diperlukan untuk melestarikan keturunan- tidak boleh dikeluarkan untuk zakat, kecuali bila orang yang mengeluarkan zakat (muzakki) itu menghendaki demikian. Masing-masing pemilik kambing tidak boleh menggabungkan hak miliknya menjadi satu, atau orang-orang yang berserikat (bekerja sama dalam kepemilikan atau perdagangan) tidak boleh memisah-misahkan hak milik masing-masing dengan tujuan menghindari kewajiban mengeluarkan zakat. Dan apa yang ada pada orang yang berserikat harus dihitung secara persentase dari hak kepemilikan masing-masing. Sementara itu apabila uang dirham (mata uang yang dicetak dari bahan baku perak) mereka telah mencapai lima uqiyah (satu uqiyah=12 dirham atau 28 gram), maka zakatnya adalah empat sepersepuluh atau 2,5 persen)." (Aziz, 1999: 105-106).

Diriwayatkan oleh Imam Mālik, Shāfi'i, dan al-Baihaqi, dari Sufyān bin Abdullah Al-Thaqāfi, bahwa Umar pernah menugaskan Sufyān Al-Thaqāfi di Thaif untuk mengumpulkan zakat. Sesuai petunjuk Umar, dalam menghitung-hitung kambing yang dimiliki oleh umat Islam, Sufyan menghitung sampai anak-anak kambing yang baru lahir sekalipun. Kemudian mereka (penduduk) bertanya, "Anda menghitung anak-anak kambing kami, sementara itu, anda tidak mau mengambilnya." Ketika Sufyan datang kepada Umar, ia menyampaikan apa yang dikeluhkan para pemilik kambing. Umar menjawab, "Benar, kita memang menghitung juga anakanak kambing yang masih digendong oleh penggembalanya -karena belum bisa berjalan dengan sempurna- sementara itu kita tidak mau mengambilnya. Kita juga tidak mau mengambil binatang ternak yang sengaja digemukkan untuk pedaging, binatang yang menyusui untuk anaknya, binatang yang bunting serta pejantan yang diharapkan bisa melestarikan keturunan. Sedangkan yang kita ambil ialah yang berumur dua sampai empat tahun (jad'ah dan thāniyah). Cara seperti ini adalah mengambil tengah-tengah antara binatang ternak yang masih kecil (berkualitas rendah) dengan yang berkualitas tinggi." Dalam riwayat lain disebutkan, "Cara seperti ini adalah tengah-tengah antara yang terkecil (berkualitas rendah) dengan yang 
terbaik." (Aziz, 1999: 106-107).

Dalam Kitab Al-Kharāj, Abu Yusuf menerangkan bahwa Umar pernah menugaskan Sufyān bin Mālik ke Basrah, ia menetap di sana dalam beberapa waktu lamanya. Kemudian dia meminta izin kepada Umar untuk ikut berjihad. Umar lalu bertanya, "Bukankah engkau kini juga berjihad?" Sufyān menjawab, "Jihad dari mana? Sementara orang-orang mengatakan aku zalim kepada mereka." Kemudian Umar bertanya, "Dalam masalah apa?" Sufyān menjawab, "Mereka mengatakan bahwa aku juga menghitung anak-anak kambing mereka yang masih kecil." Umar berkata, "Hitung semuanya, sekalipin anak kambing yang masih digendong di atas kedua pundak penggembalanya. Bukankah engkau juga membiarkan (tidak memungut) kambing yang masih menyusui, atau yang digemukkan untuk pedaging, kambing yang bunting dan pejantannya?"

Zakat sebenarya diwajibkan atas dasar ketulusan hati dan cara yang baik. Dengan demikian, mengambil harta zakat yang berkualitas tinggi sampai di luar batas kewajaran adalah dilarang. Demikianlah Umar melarang untuk mempersulit manusia dalam mengeluarkan zakat (1999: 107).

Diriwayatkan oleh Abdul Razaq dan Ibnu Shaibah, dari Sa'ad alA'raj, bahwa Umar pernah bertemu dengannya. Kemudian beliau bertanya, "Hendak pergi kemana?" Sa'ad menjawab, "Aku akan ikut berperang." Umar kemudian bertanya, "Kembalilah kepada temanmu -temannya bernama Ya'la bin Umayyah- yang sesungguhnya, bekerja dengan benar itu adalah jihad yang baik. Apabila engkau menentukan zakat binatang ternak, perhatikan yang baik, jangan melupakan pemiliknya, lalu bagilah menjadi sepertiga, kemudian biarkan pemiliknya memilih sepertiga, kemudian anda memilih dari dua pertiga yang tersisa." Dan dalam riwayat Ibnu Abi Shaibah disebutkan, "Apabila pemilik kambing menunjukkan kambingnya kepadamu, maka pisahkan jadi dua bagian, kemudian silakan anda memilih separuh dari sisa yang telah dipilih pemiliknya." (Rowasy, 1981: 351).

Diriwayatkan Imam Mālik dan Shāfi'i, dari Aisyah ra, ia berkata, "Ada seseorang lewat di depan Umar dengan membawa sekawanan kambing hasil zakat. Dalam sekawanan kambing itu, Umar melihat seekor kambing yang kantong susunya kelihatan besar karena penuh dengan susu. Maka Umar bertanya, 'Kambing apa ini?' mereka menjawab, 'Kambing hasil zakat.' 
Umar bertanya lagi, 'Apakah pemiliknya memberikan kambing ini dengan penuh ikhlas, tidak ada paksaan? Janganlah kalian membuat fitnah di kalangan umat manusia, jangan mengambil hewan unggulan umat Islam, karena itu akan bisa menyulitkan mereka dalam mencari nafkah!” (Abdul Aziz, 1999: 108; Rowasy, 1981: 357-358).

Akan tetapi bila pemiliknya menyerahkan sebagian harta yang bernilai tinggi itu dengan kemauan sendiri, maka harus diterima. Harta yang berkualitas tinggi, sengaja tidak diambil sebagai zakat adalah untuk menjaga kemaslahatan pemiliknya. Demikian pula dengan harta yang berkualitas rendah, tidak boleh dikeluarkan untuk zakat dengan tujuan menjaga kemaslahatan orang miskin (Abdul Aziz, 1999: 108). Sebagaimana dikemukakan Rasulullah s.a.w:

"Ada tiga hal, barangsiapa melakukannya, maka dia akan dapat merasakan nikmatnya iman: orang yang beribadat hanya karena Allah, dengan keyakinan, bahwa sesungguhnya tidak ada Tuhan yang berhak disembah kecuali Allah; dan memberikan zakat harta yang dicintainya, yang menunjang kebutuhannya setiap tahunnya; dan tidak mau membayar zakat dengan binatang yang telah tua, kurap, sakit, dan tidak dengan yang berkualitas rendah, tetapi yang tengahtengah dari harta kekayaannya. Sesungguhnya Allah tidak meminta harta kalian yang terbaik, dan tidak pula memerintah kalian dengan harta yang jelek."

\section{Tahun Paceklik (ramādah)}

Dalam banyak buku dijelaskan, latar belakang utamanya adalah pada masa Khalifah Umar bin Khațtāb itu di daerah Hijaz tertimpa masa peceklik yang terkenal dengan tahun ramādah.

Mayoritas riwayat sepakat mengatakan bahwa krisis tahun paceklik terjadi pada tahun 18 H (Al-Ṭabāri, 1988: 75). Namun juga terdapat riwayat yang memberikan penjelasan bahwa krisis ini terjadi pada akhir tahun $17 \mathrm{H}$ (Ibnu Khaldun, 1988: 533). Dalam suatu riwayat juga disebutkan bahwa tahun paceklik terjadi setelah haji tahun $18 \mathrm{H}$, artinya mencakup mayoritas tahun 19 H (Ibnu Sa'ad, 1990: 235). Al-Suyuṭi misalnya, menyebutkan bahwa tahun paceklik terjadi pada tahun $17 \mathrm{H}$. 
Lamanya masa paceklik ini terjadi juga terdapat perbedaan pendapat. Ibnu Abdil Barri mengatakan, "Tahun paceklik merupakan bencana berat yang menimpa banyak orang selama dua atau tiga tahun yang hujan tidak pernah turun kepada penduduk Hijaz, sehingga kondisi mereka memburuk. Tahun ini disebut tahun ramādah disebabkan karena bumi berdebu disebabkan sangat kering, dan debunya naik antara langit dan bumi seperti abu. Dan orang mengatakan tahun ramādah adalah mengisyaratkan tentang betapa beratnya musibah tahun itu." (Jaribah, 2006: 354).

Terdapat perbedaan riwayat mengenai penentuan luas daerah yang tertimpa krisis paceklik ini. Mayoritas riwayat menunjukkan bahwa krisis ini menimpa seluruh wilayah Hijaz (Ibnu Katsir, 2005: 53). Sedangkan riwayat yang lain menunjukkan bahwa krisis ini menimpa wilayah di luar Jazirah Arab, yaitu Najd, Tihamah, dan Yaman. Ketika itu Umar mengutus dua orang kaum Anshar ke daerah tersebut dengan membawa banyak unta yang dimuati makanan dan kurma untuk dibagikan kepada orang-orang yang kelaparan di sana. (Ibnu Sa'ad, 1990: 235).

\section{Pendapat Umar bin Khațțāb tentang Penundaan Penarikan Zakat Ternak Kambing yang telah Mencapai Nisab}

Kearifan Umar sebagai sahabat yang patut diteladani tampak dari pendapatnya dalam menyikapi musim paceklik. Pada masa ini pula, Umar sama sekali tidak tertarik untuk menikmati segala kemudahan yang ada, padahal Islam tidak menyuruh orang berlaku demikian. Dia melakukan itu untuk merasakan apa yang dirasakan kaum dhuafa dan orang-orang yang tidak mampu. Umar berkata, "Bagaimana saya akan dapat memperhatikan keadaan rakyat, jika saya tidak ikut merasakan apa yang mereka rasakan." Karena itulah Umar menurunkan taraf hidupnya ke tingkat hidup orangorang miskin yang makan hanya dari hidangan yang tersedia (Haikal, 2008: 363-364). Umar berani melakukan penundaan penarikan zakat binatang ternak yang terkena imbas krisis masa paceklik.

Ibnu Sa'ad juga (1990: 246) meriwayatkan:

"Muhammad bin Umar menceritakan, Talhah bin Muhammad meriwayatkan dari Hausyab bin Basyar al-Fazari, dari ayahnya, 
bahwa dia berkata, "Kami melihat pada tahun ramādah (kerusakan/ paceklik), paceklik menghanguskan ternak kami, sehingga tersisa pada banyak orang, sesuatu (harta) yang tidak ada artinya. Maka Umar tidak mengutus pada tahun itu para petugas pengumpul zakat. Lalu pada tahun depannya, dia mengutus para petugas untuk mengambil dua zakat dari pemilik hewan, lalu separuhnya diberikan kepada orang-orang yang miskin di antara mereka dan separuhnya yang lain dibawa kepada Umar. Lalu tidaklah diperoleh dari semua zakat yang berasal dari Bani Fazarah melainkan enam puluh kambing, lalu yang tiga puluh dibagikan, sedangkan tiga puluh yang lain dibawa kepada Umar. Dan Umar mengutus petugas zakat kemudian memerintahkan para petugas zakat untuk mendatangi manusia yang sekiranya masih ada."

Abu Ubaid dalam kitab al-Amwāl menerangkan, dari Yazid bin Harmaz dari Ibnu Abi Dhabab, bahwa Umar menunda penarikan sadaqah (zakat) pada tahun paceklik. Ibnu Abi Dhabab berkata, "Maka ketika manusia telah hidup (normal) kembali maka Umar mengutusku, kemudian berkata, 'ambillah zakat atas mereka untuk dua zakat sekaligus, lalu bagikanlah zakat untuk mereka dan berikan untukku sisanya." (1986: 468).

Abu Ubaid juga mengatakan, "Seorang imam boleh menunda penarikan zakat binatang ternak karena manusia tertimpa musibah (krisis), dan kekeringan, sampai menjadi subur kembali. Kemudian dibayar pada tahun depan secara penuh, sebagaimana dilakukan Umar pada tahun paceklik (1986: 705).

Pada sisi lain, Ibnu Sa'ad meriwayatkan:

Muhammad bin Umar menceritakan: Sufyan bin 'Uyainah meriwayatkan dari Ibnu Abi Najih, dari Kardam, bahwa Umar mengutus penarik zakat pada tahun paceklik, kemudian berkata: "Berikanlah zakat kepada orang yang pada masa krisis ini masih memiliki seratus kambing, dan tidak kepada orang yang dalam krisis ini masih memiliki dua ratus kambing." (Ibnu Sa'ad, 1990: 246; Lihat juga dalam Abu Ubaid,1986: 669).

Abu Ubaid mengomentari riwayat ini, maksudnya bahwa Umar berpendapat tentang dispensasi tersebut pada tahun paceklik, yaitu masa terjadinya kelaparan dan kemarau panjang yang menyebabkan harta manusia 
dan ternak mereka menjadi terkena imbasnya sehingga tidak tersisa darinya ternak yang memiliki daging dan susu, sedangkan buah-buahan dan hasil ladang menjadi puso, seperti disebutkan dalam firman Allah, "Dan sesungguhnya kami telah menghukum (firaun dan) kaumnya dengan (mendatangkan) musim kemarau yang panjang dan kekurangan buahbuahan." Maka ketika kondisi seperti itulah Umar berpendapat agar orang yang memiliki seratus kambing diberikan zakat. Tidaklah kamu melihat bahwa dia mengatakan, 'barang siapa yang tersisa padanya saat krisis ini seratus kambing,' di mana dia mensyaratkan adanya paceklik. Hal itu disebabkan nilai seratus kambing dalam kondisi seperti itu tidak melebihi sepuluh kambing pada masa makmur karena tertimpa kemarau panjang dan tidak ada rumput yang menjadi makanan. Ketika demikian itulah Umar memberikan dispensasi dalam masalah zakat karena kasihan kepada rakyatnya. Bahkan beliau kemudian mengakhirkan zakat dari mereka pada tahun itu dan tidak mengambilnya hingga mereka hidup (1986: 669-670).

Hewan ternak, seperti kambing, merupakan ukuran kekayaan pada masa itu. Ini dikarenakan, masyarakat Arab pada masa itu, misalnya kaum Badui, sangat bergantung dengan hewan ternak. Bisa dikatakan, kekayaan hewan ini merupakan tolok ukur kaya dan miskinnya penduduk desa, karena memang penduduk desa bersandar pada hal ini. Penduduk desa minum dari susunya, memakan dagingnya, dan berpakaian dengan bulu dan kulitnya (Jaribah, 2006: 361). Oleh karena itu, ketika hewan ternak terkena imbas musim paceklik, yang menjadikan hewan ternak menjadi kurus, nilai seratus kambing pada masa itu ibarat sepuluh kambing saja pada masa makmur.

\section{Tinjauan Uṣūliyyah terhadap Pendapat Umar bin Khațțāb}

Dengan menelaah riwayat Umar, diketahui bahwa Umar menjadikan zakat pada masa paceklik itu sebagai utang yang tetap harus dibayar pada tahun berikutnya. Karenanya, dalam riwayat itu dikatakan, "Lalu pada tahun depannya, dia (Umar) mengutus para petugas zakat untuk mengambil dua zakat kepada pemilik hewan."

Tentu ada sebab tertentu mengapa Umar sampai berijtihad untuk menunda penarikan zakat ini. Sebab utama penundaan itu adalah adanya 
musim paceklik yang dampaknya sangat dirasakan masyarakat. Sebagaimana disebutkan dalam berbagai riwayat, tahun paceklik terjadi pada tahun $17 \mathrm{H}$ di daerah Hijaz. Dapat digambarkan bahwa pada masa peceklik ini manusia sulit sekali memperoleh air. Pertanian juga terkena imbasnya, karena pertanian di daerah Jazirah Arab sangat tergantung hujan. Manusia sangat kekurangan bahan makanan. Umar pernah mengontrol rakyatnya di Madinah pada suatu malam di tahun paceklik. Umar tidak mendapati satu orang pun yang tertawa, atau berbincang-bincang di rumah sebagaimana biasanya. Umar tidak pula mendapati ada yang meminta-minta, Mereka pernah meminta-minta tetapi tidak ada yang dapat diberikan, akhirnya mereka tidak lagi meminta. Dampak musim paceklik tahun paceklik juga sangat dirasakan hewan ternak. Pada saat itu hewan ternak menjadi kurus dan kering karena sedikit sekali mendapat makanan.

Keadaan manusia yang sedang terhimpit kesusahan ini menjadi pertimbangan utama Umar untuk menunda penarikan zakat. Jika Umar memaksakan untuk menarik zakat pada saat itu, justru akan menambah beban kesusahan manusia. Padahal Umar dikenal sebagai khalifah sangan bijak dan wara'. Umar tidak mau berfoya-foya atau bersenang-senang di saat umatnya dalam kesusahan. Perilaku Umar ini merujuk pada keterangan Husain Haikal yang menjelaskan bahwa pada saat terjadi musim paceklik, Umar sama sekali tidak tertarik untuk menikmati segala kemudahan yang ada. Umar juga menurunkan taraf hidupnya ke tingkat orang miskin yang makan hanya dari hidangan tetrsedia. Umar menjauhi kemewahan.

Umar menunda penarikan zakat binatang ternak kambing yang telah mencapai nishab karena pemilik kambing maupun masyarakat pada umumnya tertimpa musim paceklik yang dikenal dengan tahun paceklik. Musim paceklik yang menimpa sebagian besar wilayah Hijaz ini telah menyengsarakan umat manusia pada saat itu.

Umar perlu mengeluarkan pendapat ini karena pada masa itu pemerintahan yang berlaku masih memakai sistem sentralisasi kekuasaan. Sehingga pendapat Umar akan dijalankan oleh semua daerah atau wilayah di bawah kekuasaan Islam saat itu. Meskipun Umar membagi-bagi daerah kekuasaan menjadi beberapa wilayah yang dikepalai seorang gubernur, namun sifatnya hanya sebagai pelaksana. Penentu kebijakan utama tetap 
berada di tangan khalifah.

Umar tetap memandang zakat sebagai fardhu yang telah difardhukan (diwajibkan) Allah kepada muslimin, orang yang menunaikan zakat akan mendapat ajr (pahala) dari Allah (Rowasy, t.t: 351). Oleh karena itu Umar sangat tegas ketika menghadapi persoalan zakat. Sebagai salah seorang sahabat yang terkenal wara', zuhud, dan senantiasa berupaya mendekatkan diri kepada Allah, Umar melaksanakan berbagai kewajiban yang telah difardhukan atau diwajibkan kepada hamba-Nya. Di antara kewajiban tersebut adalah persoalan penanganan zakat.

Kaidah ușūl yang lain menjelaskan, perintah ada kalanya ditentukan waktunya dan adakalanya tidak. Jika suatu perintah disertai waktu tertentu, perintah semacam itu mesti dikerjakan pada waktu yang telah ditentukan. Tetapi jika tidak ditentukan waktu, perintah (amr) berlaku sesuai kaidah;

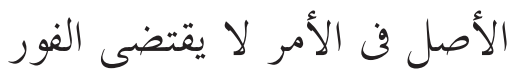

"Pada dasarnya, perintah (amr) itu tidak menghendaki dilaksanakan segera" (Rifa'i, 1973: 34-35).

Karena itu boleh ditunda mengerjakannya dengan cara tidak melalaikan perintah (pekerjaan) itu. Dalam hal ini apa yang dilakukan khalifah Umar menemukan kesesuaian. Perintah (amr) zakat dalam al-Qur'an disebutkan dalam QS. al-Baqarah: 34, al-Nisā': 77, al-Taubah: 103, dan alAn'ām: 103. Apalagi, sebagaimana dijelaskan Wahbah Zuhaily di atas, kesegeraan itu bila tidak ada uzur. Sementara dalam pendapat Umar, ia menunda atau tidak menyegerakan penarikan zakat kambing yang telah mencapai nishab, karena melihat pemilik kambing terkena uzur, dalam hal ini kambing yang digunakan untuk membayar zakat dalam kondisi kurus. Dan ini tidak memenuhi syarat hewan yang digunakan untuk membayar zakat. Meskipun kambing itu tetap dalam hitungan nishab.

Jika mengikuti ketentuan tentang nishab kambing yang ada, harusnya baik orang yang memiliki seratus maupun dua ratus kambing harus sama-sama mengeluarkan zakat. Sebab keduanya sudah mencapai jumlah nishab yang ditentukan untuk menunaikan zakat. 
Sebagaimana dijelaskan Abu Ubaid, pendapat Umar ini disebabkan karena nilai seratus kambing dalam kondisi masa paceklik tahun paceklik tidak melebihi sepuluh kambing pada masa makmur, di mana saat itu terjadi kemarau panjang dan sedikit sekali rumput yang menjadi makanan (Abu Ubaid, 1986: 669).

Sedangkan Jaribah menerangkan, selama kondisi ternak seperti itu (pada masa paceklik), maka kambing tersebut tidak memenuhi kebutuhan pemiliknya walaupun jumlahnya banyak. Sehingga Umar berpendapat agar mereka (walau kambingnya mencapai seratus ekor) termasuk orang yang berhak menerima zakat (Jaribah, 2006: 383-384).

Hewan ternak, termasuk kambing, pada masa itu merupakan ukuran kekayaan. Makin banyak hewan ternak yang dimiliki, makin tinggi pula derajat kekayaan seseorang. Ini dikarenakan karena memang penduduk desa bersandar pada hewan ini. Penduduk desa minum dari susunya, memakan dagingnya, dan berpakaian dengan bulu dan kulitnya (Jaribah, 2006: 361).

Artinya orang yang memiliki seratus kambing pada masa paceklik ini termasuk orang yang kesusahan. Hal itu disebabkan harta yang dimilikinya juga tidak bisa digunakan untuk memenuhi kebutuhan diri dan keluarganya.

\section{Keberadaan Pendapat Khalifah Umar bin Khaṭțāb tentang Penundaan Penarikan Zakat Binatang Ternak Kambing dalam Khazanah Ilmu Fiqh}

Tidak ada silang pendapat mengenai jumlah nishab kambing yang wajib dizakati. Semua sepakat bahwa nishab kambing adalah jika 40-120 ekor kambing zakatnya seekor kambing, antara 121-200 ekor zakatnya 2 ekor kambing, antara 201-300 ekor, zakatnya 3 ekor kambing, dan jika jumlahnya lebih dari 300 ekor, zakatnya seekor domba untuk setiap seratus ekor (Zuhayli, t.t: 1996; Sābiq, 1978: 78; Ash-Shidiqieqy, 1996: 124; AshShidiqieqy, 2001: 128, Ibnu Rusyd, 2000: 584; Qarḍāwi, 2004: 205, Abu Ubaid, 1986: 477).

Hanya terjadi sedikit perbedaan bila jumlah kambing itu lebih dari tiga ratus ekor. Sebagaimana diterangkan Ibnu Rusyd, Hasan bin Saleh berpendapat bahwa apabila jumlah kambing ada tiga ratus satu ekor, maka 
zakatnya empat ekor kambing. Dan apabila mencapai empat ratus satu ekor, maka zakatnya lima ekor kambing (Ibnu Rusyd, 2000: 584).

Pada sisi ini pendapat Umar juga disepakati para ulama. Hal ini karena Umar juga memakai landasan yang sama dalam persoalan jumlah nishab zakat kambing. Sejak awal menjabat sebagai khalifah, Umar seperti halnya Abu Bakar cukup tegas dalam persoalan penanganan zakat. Ia selalu mengutus petugas zakat tiap tahun untuk menarik zakat.

Namun saat terjadi musim paceklik tahun paceklik, Umar dengan bijak mengubah pendapatnya itu. Ia tidak secara mutlak mewajibkan orang yang memiliki kambing yang mencapai nishab untuk ditarik zakatya. Contohnya, Umar tidak menarik zakat orang yang memiliki serat us ekor kambing.

Bagi Umar, nilai seratus ekor kambing pada masa paceklik itu tidak beda dengan nilai sepuluh ekor pada masa normal. Artinya, karena seratus kambing itu tidak berarti apa-apa bagi sang pemilik, maka ia tidak wajib membayar zakat. Malah lebih dari itu, Umar menempatkan orang ini sebagai yang berhak menerima zakat. Dalam hal ini, umar menggunakan pendekatan kontekstual terhadap nash (al-Qur'an dan hadits) untuk memahaminya dalam menyikapi problem hukum yang ada. Sebab tidak ada nash al-Qur'an yang menerangkan tentang kebolehan menunda zakat. Sementara hadis yang ada menyebutkan, dalam hadits Abu Hurairah, "Bahwa Nabi s.a.w. ketika memaafkan Abbas yang mengakhirkan zakatnya, berkata, "Zakat itu wajib kepadanya, dan yang seumpamanya bersama dengannya" (Al-Shaukani, t.t: 159).

Dalam hal ini, tidak banyak ulama yang menyinggung. Hampir seluruh pembahasan terhenti kepada kewajiban zakat bagi orang yang memiliki kambing mencapai nishab yang ditentukan. Tidak ada pembahasan lebih lanjut bagaimana jika nishab yang dimiliki itu tidak berpengaruh banyak terhadap kelangsungan hidupnya.

Pada sisi lain, boleh dikata, pendapat Umar dipakai beberapa ulama dalam menentukan boleh atau tidaknya menunda pembayaran zakat. Salah satunya Abu Ubaid, dengan jelas ia mengatakan dalam kitab al-Amwāl, boleh menunda penarikan zakat hewan ternak kambing, hingga muzakki membayar dua zakat sekaligus dengan syarat terjadi paceklik sebagaimana dilakukan 
Umar bin Khaț̣̄āb.

Imam Ahmad juga memperbolehkan penundaan penarikan zakat. Alasan Imam Ahmad, sebgaimana dikemukakan Yusuf Qarḍāwi, dalam memperbolehkan hal itu adalah hadis Umar, bahwa orang-orang yang berada dalam keadaan sangat membutuhkan pada suatu tahun, maka Umar tidak mengambil zakat dari mereka pada tahun itu juga. Akan tetapi Umar baru mengambilnya pada tahun berikutnya (Qarḍāwi, 2004: 818).

Ulama lain yang menggunakan pertimbangan pendapat Umar untuk menunda penarikan zakat adalah Yusuf Qarḍāwi. Begitu juga TM Hashbi Ash-Shidieqy yang membolehkan menunda penarikan zakat dengan mendasarkan kepada pendapat Umar bin Khațāāb.

Pendapat Umar memang layak dijadikan pertimbangan utama bagi seorang ulama dalam melakukan. penyimpulan hukum (istinbat), hal ini karena Umar merupakan khalifah (pengganti) Nabi ke-2 yang otoritas keilmuan dan keislamannya tidak diragukan. Alasannya, meskipun Umar tidak menggunakan nash al-Qur'an dan hadits sebagai landasan utama, namun Umar mengeluarkan pendapat ini dengan menggunakan pertimbangan mașlaḥah yang bisa dibenarkan atau selaras dengan kehendak nash al-Qur'an dan hadits.

\section{Kontekstualisasi Pendapat Umar bin Khațțāb dengan Pengelolaan Zakat di Indonesia}

Indonesia merupakan negara dengan penduduknya mayoritas beragama Islam. Hal ini menjadi kebanggaan tersendiri bagi kita sebagai umat Islam. Namun kebanggaan itu akan segera sirna bila menengok dari catatan tentang jumlah penduduk miskin yang ada. Artinya mayoritas orang miskin itu adalah muslim.

Meskipun Indonesia tidak menjadikan agama sebagai dasar utama, namun falsafah Negara ini dan Undang-Undang Dasar yang ada mengakui dan memungkinkan peran agama di situ. Dalam hal ini adalah kemungkinan pejabat Negara untuk membantu pelaksanaan pemungutan zakat dan pendayagunaannya (Hasan, 1995: 52). 
Salah satu buktinya adalah lahirnya UU No. 38 Tahun 1999 tentang pengelolaan zakat. UU yang disahkan pada tanggal 23 September 1999 ini melingkupi organisai pengelolaan zakat, metode pengumpulan zakat, pendayagunaan zakat, pengawasan, dan sanksi.

Memang terdapat perebedaan mendasar antara pengelolaan zakat di tanah air saat ini dengan pengelolaan zakat pada masa awal keberadaan Islam. Pada saat itu, zakat dikelola oleh penguasa yang ada, bahkan zakat termasuk salah satu sumber utama pendapatan Negara. Konsekuensinya penguasa atau pemerintah dapat memaksa untuk menarik zakat dari rakyat yang termasuk muzakki (Ali, 2006: 131-136). Di luar zakat, terdapat khums, jizyah, kharāj, dan ushr yang merupakan sumber utama penerimaan negara pada masa awal Islam. Hal tersebut berbeda dengan prinsip yang tertera dalam UU tentang pengelolaan zakat yang berlaku di Indonesia. Muzakki diberi kebebasan untuk melaporkan atau tidak bahwa dirinya sudah mempunyai kewajiban membayar zakat.

Merujuk pada kondisi topografi Indonesia, boleh dikata Indonesia termasuk wilayah yang sengat rentan terkena bencana. Posisi geografis Indonesia yang berada di jalaur ring patahan, membuat beberapa wilayah di tanah air menjadi langganan gempa bumi. Pada tahun 2004 misalnya, patahan di dasar laut di daerah Aceh menyebabkan gempa berkekuatan besar dan melahirkan tsunami yang meluluh-lantahkan Bumi Serambi Makkah saat itu.

Berangkat dari hal ini, kiranya fatwa hukum tentang persoalan zakat di suatu daerah yang tertimpa bencana juga perlukan. Secara umum bencana menyengsarakan manusia yang ada di dalamnya. Dan pada saat yang bersamaan, kadang tidak dipungkiri pula ada orang yang mempunyai harta yang sebenarnya harus dikeluarkan zakatnya. Nah, pada kondisi yang demikian, apakah ia masih harus mengeluarkan zakat pada saat itu juga, atau ia diperbolehkan menundanya sebagaimana kasus yang terjadi pada masa Umar.

Sebagai contoh, misalnya ketika terjadi bencana banjir di suatu daerah yang sangat sulit dijangkau transportasi, maka permasalahan utama yang timbul pada saat itu adalah kebutuhan pangan yang harus segera dipenuhi. Pada saat yang seperti ini, maka antara orang yang memiliki emas yang 
mencapai nishab dan memenuhi syarat untuk mengeluarkan zakat, tidak jauh beda dengan orang yang tidak memiliki emas. Sebab pada saat itu yang dibutuhkan adalah pangan. Dan emas seolah tidak menemukan nilai. Emas tadi akan kembali kepada niliainya yang semula setelah daerah yang tertimpa bencana tadi kembali normal. Dalam hal ini, pemilik emas tadi tetap wajib mengeluarkan zakat emasnya meski tidak segera. Atau dengan kata lain ditunda sampai pada waktu sesudahnya.

Tidak dapat dinafikan, saat ini di Indonesia berkembang lembagalembaga non-pemerintah yang mengurusi persoalan zakat, infaq, dan shadaqah. Zakat yang berhasil mereka kumpulkan juga tidak sedikit. Tidak jarang pula, hasil pengumpulan zakat antar satu daerah dengan daerah lain terdapat perbedaan yang signifikan.

Bila pada masa tertentu suatu daerah tertimpa krisis keuangan atau masa paceklik, dan terpaksa dilakukan penundaan penarikan zakat, maka yang paling merasakan imbasnya adalah golongan fakir dan miskin. Dua golongan ini adalah yang paling diutamakan untuk menerima zakat. Hal itu dikarenakan pada dasarnya mustahiq zakat sangat terbantu dengan adanya zakat ini. Maka tatkala dilakukan penundaan penarikan atau pembayaran zakat, maka golongan ini tertimpa kemalangan dua kali sekaligus. Pertama mereka sudah sengsara akibat masa paceklik, dan kedua tambah sengsara karena tidak menerima zakat.

Dalam hal ini kita bisa belajar dari pengelolaan zakat yang dilakukan sahabat Umar bin Khațtāb saat menyikapi masa paceklik tahun paceklik. Pada saat itu, dengan melihat kondisi yang ada, Umar dengan bijaksana menunda melakukan penarikan zakat di daerah yang tertimpa musim paceklik ini. Pada saat bersamaan, Umar meminta para gubernurnya yang ada di beberapa wilayah untuk membantu daerah yang kesulitan ini, meskipun hal ini berlawanan dengan pendapat Umar yang tidak mengijinkan zakat di suatu daerah disalurkan untuk daerah lain. Dengan demikian, dapat diambil pemahaman, pendikotomian zakat per daerah adalah sebagai dasar praktik yang mengharuskan sistem tersebut membagikan hasil zakat kepada masyarakat setempat yang berhak. Ketika harta zakat pada suatu daerah berlimpah dan melebihi kebutuhan, maka akan diberikan kepada daerah paling dekat yang mengalami kekurangan (Al-Ba'ly, 2006: 123). 


\section{Penutup}

Dari pembahasan di atas, ada beberapa poin penting yang perlu dicatat. Di antaranya adalah bahwa penundaan penarikan zakat binatang ternak yang telah mencapai nishab hanya diberlakukan kepada binatang ternak yang terkena imbas dari musim paceklik. Musim paceklik itu menjadikan kualitas binatang ternak menurun drastis. Kebijakan Umar memberikan zakat kepada orang yang memiliki kambing sejumlah nishab dilandasi oleh kondisi orang tersebut juga mengalami kesukaran. Seratus kambing yang ia miliki tidak memberi pengaruh berarti terhadap kelangsungan hidupnya pada saat itu, karena memang binatang ternak merupakan tempat menggantungkan hidup. Dengan kata lain, Umar dalam menentukan kriteria pembayar zakat, tetap melihat dan memastikan bahwa pembayar tersebut adalah benar-benar orang yang mampu. Umar akan menangguhkan penarikan zakat kepada pembayar meski hartanya telah mencapai nishab bila ia mengalami kesulitan dan kesusahan.

Di samping itu, dalam khazanah ilmu fiqh, penundaan penarikan zakat merupakan suatu keniscayaan, meskipun para fuqaha' lebih mengedepankan agar zakat dibayarkan segera. Apa yang dilakukan Umar bin Khatțāb dengan menunda penarikan zakat dijadikan salah satu pertimbangan oleh beberapa ulama dalam membolehkan menunda pembayaran zakat.

Kebijakan Umar tersebut, dapat diterapkan di Indonesia khususnya, yang merupakan negara yang rawan tertimpa bencana alam. Penundaan dalam penarikan zakat oleh Umar bisa menjadi salah satu pertimbangan untuk menunda pembayaran zakat hingga suatu daerah kembali kepada keadaan seperti sedia kala.

\section{DAFTAR PUSTAKA}

Al-Ba'ly, Abdu al-Hamid Mahmud. 2006. Ekonomi Zakat: Sebuah Kajian Moneter dan Keuangan Syari'ah, (penerj. Muhammad Abqary Abdullah Karim) Jakarta: PT Raja Grafindo Persada.

Al-Harithi, Jaribah bin Ahmad. 2006. Al-Fiqhi al-Iqtiṣādi Li Amīri alMukminīn Umar ibn al-Khatțāb (terj. Fikih Ekonomi Umar bin Khatab), Jakarta: Khalifa. 
Al-Jauzi, Ibnu. Manaqib Amirul Mukminin Umar ibn Khațtāab, Beirut: Dar al-Kitab al-Ilmiyyah.

Ali, K. 1995. A Study of Islamic History (penerj. Adang Affandy). Bandung: Bina Cipta.

Ali, Nuruddin Mhd. 2006. Zakat Sebagai Instrumen Kebijakan Fiskal, Jakarta: PT Raja Grafindo Persada.

Al-Nasā'i, Imam. 1991. Kitāb al-Sunan al-Kubra, Juz II, Beirut: Dār al-Kutub al-'Ilmiyyah.

Ash-Shidieqy, TM. Hasbi. 1996. Pedoman Zakat, Semarang: PT Pustaka Rizki Putra.

2001. Hukum-Hukum Fiqh Islam, Semarang: Pustaka Rizki Putra.

Ashraf, Muhammad. t.t. Sistem Ekonomi Pemerintahan Umar ibn al-Khatab. Jakarta: Pustaka Firdaus.

Al-Suyuṭi, Jalaludin. t.t. Tārīkh al-Khulafā'. Beirut: Dār al-Kutub al'Ilmiyyah.

Al-Tabari. 1987. Tārīkh al-Umam wa al-Mulūk. Beirut: Dār al-Fikr.

Al-Tirmidhi. t.t. Sunan al-Tirmidhi. Juz V. Beirut: Dār al-Kutub al-'Ilmiyyah.

Azizy, A. Qodri. 2003. Melawan Globalisasi: Reinterpretasi Ajaran Islam (Persiapan SDM dan Terciptanya Masyarakat Madani), Yogyakarta: Pustaka Pelajar.

Baltaji, Muhammad. 2005. Metodologi Ijtihad Umar bin al-Khathab, (penerj. Masturi Irham), Jakarta: Khalifa.

Bek, Hudhori. 1982. Itmām al-Wafa, Beirut: Maktabah Tsaqafiyah.

Chapra, M. Umer. 2000. Islam dan Tantangan Ekonomi, Jakarta: Gema Insani Press.

Effendi, Satria. 2008. Ushul Fiqh. Jakarta: Kencana, cetakan ke-2.

Farih, Amin. 2008. Kemaslahatan dan Pembaharuan Hukum Islam, Semarang: Walisongo Press.

Haikal, Muhammad Husain. 2008. Umar bin Khațtāb (judul asli Al-Faruq Umar), Bogor: Pustaka Litera Antar Nusa.

Hasan, KN Sofyan. 1995. Pengantar Hukum Zakat dan Wakaf, Surabaya: Al-Ikhlas.

Hasjmi, A. 1979. Sejarah Kebudayaan Islam. Jakarta: Bulan Bintang.

Hitti, Philip K. 2005. History of the Arabs, Rujukan Induk Paling Otoritatif tentang Sejarah Peradaban Islam. Jakarta: PT Serambi Ilmu.

Karim, M. Abdul. 2007. Sejarah Pemikiran dan Peradaban Islam, Yogyakarta: Pustaka Book Publisher. 
Kathīr, Ibnu. 2005. Tartīb wa Tahdhīb Kitāb al-Bidāyah wa al-Nihāyah, (terj. Al Bidayah Wan Nihayah Masa Khulafa'ur Rasyidin), Jakarta: Dār al-Ḥaq.

Khaldun, Ibnu. 1988. Tārìkh Ibni Khaldun, Juz II, Beirut: Dạr al-Fikr.

Kholaf, Abdul Wahab. 1999. Ilmu Ushul Fikih, Jakarta: Rineka Cipta.

Mubarok, Jaih. 2005. Ijtihad Kemanusiaan. Bandung: Pustaka Bani Quraisy.

Mufrodi, Ali. 1997. Islam di Kawasan Kebudayaan Arab. Jakarta: Logos.

Qarḍāwi, Yusuf. 2004. Fiqhu al-Zakāh. Terj. Hukum Zakat: Studi Komparatif Mengenai Status dan Filsafat Zakat Berdasarkan Qur'an dan Hadits, Bogor: Pustaka Litera Antar Nusa.

Quṭb, Muhammad Ali. t.t. Al-Khulafau al-Rasyidun. Beirut: Manahil alGhurfan.

Ridho, Muhammad. t.t. Umar ibn al-Khațțāb al-Fārūq. Beirut: Dār al-Kutub al-Ilmiyyah.

Rifa'i, Moh. 1973. Ushul Fiqih. Bandung: PT Al-Ma'arif.

Rofiq, Ahmad. 2004. Fiqh Kontekstual: Dari Normatif ke Pemaknaan Sosial, Yogyakarta: Pustaka Pelajar.

Rowasy, Muhammad. Mausū'ah Fiqh Umar ibn Khațtāb. Diunduh dari www.almesykat.com,

Rusyd, Ibnu. t.t. Bidayatul Mujtahid, Analisa Fiqih Para Mujtahid. Jakarta: Pustaka Amani.

Sa'ad, Ibnu. 1990. Al-Ṭabaqāt al-Kubra. Beirut: Dār al-Kutub al-Ilmiyyah.

Sabiq, Sayyid. 1978. Fikih Sunnah 3, Bandung: PT Al-Ma'arif.

Shihab, M. Quraish. 2002. Tafsìr al-Miṣbāh: Pesan, Kesan, dan Keserasian al-Qur'an, Jakarta: Lentera Hati.

Sholikhin, HM. 2005. Sejarah Peradaban Islam, Semarang: Rasail.

Ubaid, Abu. 1983. Kitāb al-Amwāl, ditahqiq oleh Kholil Muhammad bin Haras, Beirut: Dār al-Fikr al-Mu'āșir.

Yafie, Ali. 1994. Menggagas Fiqih Sosial: Dari Soal Lingkungan Hidup, Asuransi Hingga Ukhuwah. Bandung: Penerbit Mizan.

Yatim, Badri. 2004. Sejarah Peradaban Islam. Jakarta: PT Raja Grafindo Persada.

Zuhaili, Wahbah. 1989. Al-Fiqhu al-Islamy wa Adillatuhu, juz III, Damaskus: Dār Al-Fikr. 